\title{
Correction to: Mixed precipitation occurrences over southern Québec, Canada, under warmer climate conditions using a regional climate model
}

\author{
Dominic Matte $^{1} \mathbb{D} \cdot$ Julie $M$. Thériault ${ }^{1} \cdot$ René Laprise $^{1}$
}

Published online: 23 May 2018

(c) Springer-Verlag GmbH Germany, part of Springer Nature 2018

\section{Correction to: Climate Dynamics}

https://doi.org/10.1007/s00382-018-4231-2

The Introduction section of the article, in the fourth line, a mathematical expression " $\left(\mathrm{T}>0{ }^{\circ} \mathrm{C}\right)$ " should be " $\left(\mathrm{T}<0{ }^{\circ} \mathrm{C}\right)$ ". The original article has been corrected.

The original article can be found online at https://doi.org/10.1007/ s00382-018-4231-2.

\section{Dominic Matte}

mattedominic3@gmail.com

1 Department of Earth and Atmospheric Science, Centre ESCER, Université du Québec à Montréal (UQAM), P.O. Box 8888, Downtown Station, Montréal, QC H3C 3P8,

Canada 